\title{
Administration of Pretrial Release and Detention: A Proposal for Unification
}

Accused persons whose guilt or innocence has not yet been adjudicated constitute a distinct class of individuals. Though presumed innocent, they may be subjected to those restrictions necessary to ensure their appearance at all judicial proceedings. These restrictions, or their absence, define their pretrial status. The goal of the pretrial status decisionmaking process is to determine and impose upon each the least restrictive conditions necessary to ensure appearance. ${ }^{1}$

Whether or not this goal is achieved depends largely upon three factors. First, the decisionmaker who makes the initial pretrial status determination must have the authority to impose a variety of possible restrictions and must have the information necessary for the selection of the appropriate ones. Second, some decisionmaker must be able to review and adjust the initial status continually in order to correct "mistakes" and to respond to changes in the defendant's situation. Third, some authority must be able to assess accurately the needs of the various status alternatives within the pretrial process, set priorities, and allocate resources according to those priorities.

Inadequacy in all three of these areas has led to the imposition

1. This concept is based on the constitutional requirement that bail must not be "excessive," U.S. ConSr. amend. VIII, and the presumption of innocence, as was made clear in Stack v. Boyle, 342 U.S. 1, 4, 5 (1951):

Unless this right to bail before trial is preserved, the presumption of innocence, secured only after centuries of struggle, would lose its meaning.

- .

Since the function of bail is limited, the fixing of bail for any individual defendant must be based upon standards relevant to the purpose of assuring the presence of that defendant.

See Bandy v. United States, 81 S. Ct. 25 (Douglas, Circuit Justice, 1960); Reynolds v. United States, 80 S. Ct. 30, 32 (Douglas, Circuit Justice, 1959); United States v. Leathers, 412 F.2d 169 (D.C. Cir. 1969); United States v. Cowper, 349 F. Supp. 560 (N.D. Ohio 1972); United States v. Melville, 309 F. Supp. 824, 826 (S.D.N.Y. 1970). Recent court decisions condemning the physical conditions of various jails in the country have focused on the requirement of minimal restrictions. See notes 74 \& 76 infra.

As evidenced by the debate over preventive detention, some would argue that pretrial restrictions should be aimed at protecting the safety of the community as well as encouraging appearance in court. While this point of view has been rejected by appellate courts, see, e.g., In re Underwood, 9 Cal. $3 \mathrm{~d}$ 345, 508 P.2d 721, 107 Cal. Rptr. 407 (1973), its acceptance, or the acceptance of any other purposes for pretrial restrictions, would not necessarily be incompatible with the proposals presented in this Note. 
of unnecessary restrictions on many pretrial defendants. ${ }^{2}$ In an attempt to remedy the situation, jurisdictions have proposed a variety of pretrial release projects during the last decade. Although laudatory, these piecemeal reforms have had limited impact on the basic inadequacies in pretrial status decisionmaking. The reasons for this may be quite varied. Inadequate funding, a poorly trained or incompetent staff, or opposition from other organizations may all be involved. Several recent reforms, however, indicate that a key difficulty may be related to the administrative structure of the pretrial status decisionmaking process. These reforms have been aimed at coordinating the efforts and functions of usually separate projects. This particular approach to comprehensive reform should be encouraged and carried to its logical conclusion: the creation of a single administrative agency to deal with all criminal defendants, whether released or detained, during the period between arrest and adjudication.

2. Commentators have concluded that the most onerous restriction, detention, is imposed far more frequently than is necessary. See, e.g., President's Commission on Law ENFoRCEMENT AND ADMinistration of JUSTICE, TASK Force Report: CoRrecilons 23-25, 168 [hereinafter cited as TiSK FORCE REl'onT: Corkrcnons]. Experimental projects have demonstrated the validity of this conclusion. For example, during the three years that the Vera Institute of Justice operated the Manhattan Bail Project, 3,505 defendants were released on their own recognizance on the recommendation of the Vera staff. Although many of these persons would have been detained had it not been for the project, only $56,1.6$ percent of the total, failed to appear. VERI INSrITU1E of JUsirci,

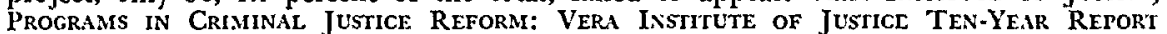
1961-1971, at 34, 35 (1972) [hereinafter cited as VERA TEN-Y'EAR REPORT].

The District of Columbia Bail Project obtained release without bail for 2,160 de. fendants in two and one-half years. Only three percent failed to appear. R. Mrocleus, BAIL REFORM in THE NATION's C.Al'ITAL 31 (1966).

During 1964-69 the Des Moines Pre-Trial Release Project obtained the relcase of 3,800 persons. Only 2.4 percent failed to appear for trial. National Couscil on CrimL and Delinquency, Des Moines Community Corrections Project: "Eviluation Report Number Two 5-6 (1972) [hereinafter cited as Des Moniss RePOrT].

A New Haven study found that nearly one-half of those held in jail because of inability to make bond would meet Manhattan Bail Project standards for release on own recognizance. Brockett, Presumed Guilty: The Pre-Trial Detainee, 1 Yale RLv. LAw \& Soc. ACTIoN, Spring 1971, at 10, 15 .

Partly as a result of unnecessary restrictions, pretrial detention predominates over post-conviction detention as the major cause of incarceration in this country. In Connecticut, approximately 70 percent of the persons who spend time in jail prior to trial serve no time after conviction. Freed, Curtis, Anduri \& Terrell, Interim Report: The Pilot Redirection Center at the New Haven Community Correctional CenterThe First Eight Months 24 (1972) [hereinafter cited as Redirection Center Report]. This state of affairs is not peculiar to Connecticut. See, e.g., Foote, Campelling A $p$ pearance in Court: Administration of Bail in Philadelphia, 102 U. P.. L. REv. 1031, 1053 (1954) [hereinafter cited as Bail in Philadelphia]; Plaintiff's Memorandum at 13, Bellamy v. Judges and Justices Authorized to Sit in the New York City Criminal Court and the New York State Supreme Court in New York County, 41 App. Div. 2d 196, 342 N.Y.S.2d 137 (App. Div. 1973) [hereinafter cited as Plaintiff's Memorandum 1; Hearings on S.2S3S, S.2S39, and S.2StO Before the Subcomm. on Constitutional Rights and the Subcomm. on Improvements in Judicial Machinery of the Senate Comm. on the Judiciary, 88th Cong., 2d Sess. 44-45 (1964) (in 1963 approximately 22,340 persons were detained before trial by order of the federal courts but only 13,600 were later sentenced to prison). 


\section{The Pretrial Status Decisionmaking Process}

\section{A. Inadequacies}

The most common restriction placed upon pretrial defendants is the requirement of bail. Unfortunately, few jurisdictions have developed a systematic method for collecting and presenting information relevant to the setting of bail and the decision is usually made so quickly that the defendant himself has little opportunity to present such information. ${ }^{3}$ As a result the bail amount is almost invariably set without regard to the defendant's ability to meet that figure. Even if information is available, the decisionmaker is typically constrained by a lack of pretrial status alternatives. In most jurisdictions his only options are to release the defendant on his own recognizance or to set money bail. Thus, to avoid detention a defendant must either meet the requirements for unconditional release or be financially able to post bail. And once detained, he is unlikely to have his status reviewed in light of changing circumstances.

\section{B. The Response: Piecemeal Reform}

\section{Single Projects}

A variety of reforms have been adopted in response to this inadequacy of information and alternatives. Each has shown success in improving the pretrial status decisionmaking process by imposing less restrictive conditions on defendants without producing an unacceptable failure to appear rate or substantially increasing costs. The success of each reform, however, has been limited in that not one of them adequately meets all the needs of that process.

3. An observer in the New York City Criminal Court, New York County, reported that in cases in which a bail or parole decision was made, the total elapsed time varied from ninety seconds to three minutes. He also reported that "[t]he atmosphere at the court sessions was hurried and frenetic. In each courtroom, there was a constant swirl of people creating a high volume of noise and distraction." Plaintiff's Memorandum, supra note 2, at A44, A45. As a result a defendant may have high bail set on the basis of a thirty second session before the judge, only to be released when he makes a second appearance and in an additional few minutes is able to set forth information which should have been presented at the initial session. One study estimated that 40 percent of the persons who spend time in pretrial detention in New Haven suffer this fate. Olson, Minutes in Court, Weeks in Jail: A Study of Pretrial Detention 13 (1973) (unpublished manuscript in the Yale Law School Library).

4. The amount of bail set is usually related to the seriousness of the crime charged and is determined by reference to a schedule kept by the prosecutor. See D. FREED \& P. Wald, BAIL IN THE UNITED STATES: 1964, at 9-21 (1964). In many jurisdictions the prosecutor's bond recommendations are followed by the court in virtually every case. See, e.g., Plaintiff's Memorandum, supra note 2, at A44 (New York); Bail in Philadelphia, supra note 2, at 1042. 


\section{a. Release on recognizance (ROR)}

The first attempt at improving the initial status decision was initiated by the Manhattan Bail Project of the Vera Foundation in 1961.5 The main hypothesis of this experiment and of the projects which have followed the Vera procedures ${ }^{6}$ was that more persons could successfully be released on their own recognizance if verified information concerning their character and roots in the community were available to the court at the time of the initial bail decision. ${ }^{7}$

Law students were employed to interview defendants before their first appearance in court. If the defendant met the project's criteria, ${ }^{\mathrm{s}}$ project officials recommended to the judge that the defendant be released before trial. If this recommendation was accepted by the judge, the project utilized an elaborate notification procedure to increase the likelihood of appearance. ${ }^{9}$

Some jurisdictions have allowed the initial status determination to be made prior to the defendant's court appearance by permitting the arresting officer, ${ }^{10}$ a stationhouse officer, ${ }^{11}$ or some other of-

5. See Ares, Rankin \& Sturz, The Manhattan Bail Project: An Interim Report on the Use of Pre-Trial Parole, 38 N.Y.U.L. REv. 67 (1963) [hereinafter cited as Manhallan Bail Project]; Botein, The Manhattan Bail Project: Its Impact on Criminology and the Criminal Law Processes, 43 Texas L. REv. 319 (1965). The Vera Foundation became the Vera Institute of Justice in 1966.

6. The Manhattan Bail Project served as a prototype for projects throughout the country. By 1965 at least 42 similar release projects were in operation. B.IIL AND Summons: 1965, at 8 (Nat'l Conf. on Bail \& Criminal Justice 1966). A recent survey found that there are now approximately 70. Partridge, Strategy Paper on the Pre-Trial Release of Adults 7, March 17, 1972 (unpublished memorandum on file with the Yale Law Journal). See Hawthorne \& McCully, Release on Recognizance in Kalamazoo County, MICH. ST. B.J., July 1970, at 23; Howard \& Pettigrew, ROR Program in a University City, 58 A.B.A.J. 363 (1972); McCarthy \& Wahl, The District of Columbia Bail Project: An Illustration of Experimentation and a Brief for Change, 53 GEo. L.J. 675 (1965); Note, The Development of Release on Recognizance and the Dane County Bail Study, 1965 WIS. L. REv. 156 (1965).

7. Manhattan Bail Project, supra note 5, at 68 .

8. The factors which. were considered in deciding whether to recommend pretrial parole were:

1. Present or recent residence at the same address for six months or more.

2. Current employment or recent employment for six months or more.

3. Presence of relatives in New York City with whom the pretrial defendant is in contact.

4. No previous convictions.

5. Residence in New York City for ten years or more.

Pretrial parole was recommended if the defendant met at least two of the five criteria. Id. at 72 .

9. Id. at 74-75. The project found court notification procedures inadequate. Court records often carried inaccurate information as to the defendant's name or address, and notice of the scheduled court appearance was written and in English. These inadequacies led to, many failures to appear. The project therefore sent letters in the defendant's own language and made phone calls to illiterates.

10. This procedure is termed "citation release" and is permitted in "probably nat more than" six jurisdictions. Partridge, supra note 6 , at 7 . See Berger, Police Field Citations in New Haven, 1972 Wisc. L. REv. 382 (1972); Feeney, Citation in lieu of Arrest: The New California Law, 25 VAND. L. Rev. 367 (1972).

11. New Haven, Connecticut, has a stationhouse ROR project separate from its citation release program. New Haven Department of Police Services General Order 71-4, 
ficial12 to release defendants on a summons, citation, or notice to appear. Such programs do not of course preclude a later judicial ROR decision based upon more complete information.

These projects have demonstrated that a large percentage of detained pretrial defendants would appear for court proceedings even if they did not post money bail.13 Indeed, the failure to appear rate for defendants released ROR is often as good as the rate for those who make bail. ${ }^{14}$ Moreover, the costs of such projects have been more than offset by the savings to the government resulting from reduced incarceration. ${ }^{15}$ An ROR project, however, is of little use to a pretrial defendant who is found unsuitable for unconditional release $^{16}$ or who cannot establish his suitability until after the initial status decision has been made.

April 22, 1971, at 4. The California citation release statute combines release by the arresting officer and release at the stationhouse under its heading. CaL. PENAL CODE $\$ \$ 853.6$ (a), (i) $(1970)$.

12. For example, Connecticut has created a Bail Commission whose members have the authority to raise or lower the bail set by the police, to release the arrestee on his own recognizance, or to release him with conditions. O'Rourke \& Carter, The Connecticut Bail Commission, 79 YALE L.J. 513 (1970).

13. See note 2 supra. Although 14.5 percent of the arrestees released by the New Haven Police Services Citation Program did not appear for their first court date, the failure to appear rate was reduced to 5.3 percent when the case was continued one week and the defendant was contacted by the Bail Commission. Berger, supra note 10, at 407-08. Of those released by the Bail Commission in New Haven, 8.2 percent failed to appear at the scheduled time. T. O'Rourke, Annual Report of the Chief Bail Commissioner, Circuit Court, May 17, 1972, chart 4. They were immediately notified by letter or telephone. Half then appeared for their next court date, reducing the failure to appear rate to 4.1 percent. $I d$. at charts 4,5 .

14. See, e.g., Law Enforcenent Assistance Administration, U.S. Del't of Justice, Community Bised Corrections in Des Moines 12 (1973). But cf. S. Schaffer, Bail and Parole Jumping in Manhattan in 1967, August 1970 (unpublished report of the Vera Institute of Justice). While only 1.6 percent of those recommended for release by the Vera Institute during 1961-1964 failed to appear, see note 2 supra, 9.4 percent of those recommended for release by the Office of Probation (which took over operation of the project from the Vera Institute) from January 1, 1967, to March 30, 1967, failed to appear. Only 4.4 percent of those who posted bond failed to appear. Schaffer states that the differences between Vera Institute and Office of Probation administration of ROR included the techniques used to assure the appearance of defendants in court, the staff and its motivation, and the recommendation policy with respect to suspected addicts. Id. at 33 . His findings point to the need for more extensive notification procedures and for an agency which has the capacity to supervise all releasees.

15. During the period August 1, 1964, through July 31, 1968, the San Francisco Bail Project saved the city at least $\$ 1,240,000-$ ten times more than the cost of financing the program. The 6,377 released defendants would have averaged 39 days in jail. l'rison costs were conservatively estimated at five dollars per day; therefore, each release saved $\$ 195$, or a total of $\$ 1,240,000$. Not included were savings on welfare payments to detained defendants' families or increased tax reventics from relcased dcfendants who were able to keep their jobs. Total cost for the project for four years was S136,900. Levin, San Francisco Bail Project, 55 A.B.A.J. 135, 136 (1969). Toward the end of the Manhattan Bail Project experiment, the average cost per release was about \$28.20. The average cost for detaining a defendant was \$186. L. Friedman, The Evolution of Bail Reform 88, December 1972 (working paper of the Center for the Study of the City and its Environment, Institution for Social and Policy Studies, Yale University).

16. VERA TEN-YEAR REPORT, supra note 2, at 36. 


\section{b. Conditional release}

Some jurisdictions have sought to provide the decisionmaker with status alternatives along the spectrum between detention and traditional ROR by permitting release under a variety of conditions. ${ }^{17}$ The types of conditions imposed include remaining within the court's jurisdiction, maintaining a fixed place of abode, avoiding certain associations, finding employment, and making periodic checkins with the police, probation office, or court. ${ }^{1 s}$ When the alternative of imposing such conditions has been available for use by decisionmakers, the result has been the release of more defendants before trial. ${ }^{19}$

These projects permit the release of high risk defendants who cannot make bail or satisfy ROR requirements. Unless combined with an ROR program, however, conditional release may result in the unnecessary, wasteful, and oppressive supervision of defendants who would appear in any event.

\section{c. Ten percent bail}

"Ten percent bail" is another alternative to the traditional monetary bail system. Instead of paying as much as a 10 percent nonrefundable premium to a professional bondsman, the accused executes a bond for the amount set by the court and deposits 10 percent of the amount with the court clerk. ${ }^{20}$ Upon compliance with the conditions of his bond, the accused is refunded all or a

17. See D. Freed \& P. WALD, supra note 4, at 73-77. The Federal Bail Reform Act of 1966 encouraged the use of conditional release. 18 U.S.C. $\$ 3146(a)(1970)$. The American Bar Association has also endorsed this procedure. AMERICiN BAR Assoctation Project on Siandarus for Criminal Jusilce, Standarus Relailng to l'reirial Releisl $9,18,26-27,57$ (1968).

18. For the conditions imposed in one jurisdiction sce Districr of Columbia B.siL. Agency, HaNdbook on Procedure 96-106 (1972) [hercinafter cited as D.C. Ball Agency HANDBOOK].

19. In 1970 the Des Moines Model Neighborhood Corrections Project was established to obtain the release of the approximately 400 defendants per year who did not post bond or qualify for the Pre-Trial Release Project (see note 2 supra) but who might appear for trial if provided with some supervision. Defendants are interviewed at the jail by project staff members who then arrange a rehabilitative program. If the court accepts the project's recommendation, the defendant is released to the program. During its first two years the program obtained the relcase of 281 defendants. Of the defendants whose cases were closed 97.6 percent appeared for trial, about the same percentage as for money bond and ROR releasecs in that jurisdiction. Drs Mrors. REl'OR', supra note 2, at 38-40. The project has resulted in a cost savings of nearly $\$ 200,000$ during its first three years. National Council on CRime and Delinquincr, A Summary of the Evaluation Findings for Tilke Componenis of $11 \mathrm{l}$. Fifill Judicial Disiricr Dei'ariment of Couri Servicfs, Srate of Iowa 4 (1973).

20. Several jurisdictions have authorized the use of such procedures. See Rice \& Gallagher, An Alternative to Professional Bail Bonding: $A$ 10\% Cash Deposit for Connecticut, 5 ConN. L. REv. 143, 147 (1972). 
very high proportion of the cash deposit. ${ }^{21}$ This procedure thus eliminates the bondsman ${ }^{22}$ and substantially reduces the cost to the defendant who appears in court. Appearance rates have been shown to be at least as good for those who post the 10 percent bond as for those who post a surety bond. ${ }^{23}$ Unfortunately, even this more reasonable bail procedure is beyond the reach of many defendants of limited financial means ${ }^{24}$ and in any event is unavailable in many jurisdictions.

\section{d. Diversion projects}

Diversion projects ${ }^{25}$ offer a limited group of accused persons not only an opportunity to be free before trial, but also an opportunity to avoid trial itself and the onus of a criminal record. Typically, the projects are aimed at first offenders accused of minor crimes. ${ }^{20} \mathrm{~A}$ continuance is requested in the case, during which time

21. Bowman, The Illinois Ten Per Cent Bail Deposit Provision, 1965 U. ILx. L.F. 35,37 (1965).

22. In Philadelphia, during the first $91 / 2$ months of the Ten Percent Cash Bail Program (Feb. 23, 1972-Oct. 31, 1972), 89.5 percent of defendants who made bail took advantage of the program. Philadelphia Common Pleas and Municipal Court Pre-Trial Services Division, Ten Percent Cash Bail Statistics, 1972.

23. During 1964, in the First District of the Municipal Court Division of the Circuit Court of Cook County, bondsmen wrote 35,571 bonds, 11.4 percent of which were forfeited; 27,956 bonds were posted under the 10 percent program, only 7.7 percent of which were forfeited. Bowman, supra note 21, at 39. During 1969, in the same district, 84,202 bonds were posted under the 10 percent program, 11.7 percent of which were forfeited. Murphy, Revision of State Bail Laus, 32 Oн1о ST. L.J. 451, 476 (1971).

Perhaps there is a greater incentive to appear under the 10 percent bail program than under a regular bail bond because the money is refunded to the accused or to his family if he appears. Some programs also provide for notification of those who are released on 10 percent bail. The Philadelphia Ten Percent Cash Bail Program requires the defendant to report by telephone to the program office the day following his release. Twenty-one days before his next court date, the defendant is reminded of that date by letter. He is then required to phone the program office again. Failure to cooperate may result in the defendant's incarceration. Philadelphia Common Pleas and Municipal Court, Pre-Trial Services Division, Operational Phases of the 10\% Cash Bail Program 2 (1972).

24. Proponents of the 10 percent bail idea have always acknowledged that by itself it does not meet the needs of the indigent defendant. See Bowman, supra note 21, at 40. For a critical view of such programs see Peters, Refundable Bail as Good for Poor as Lotteries Are, The Philadelphia Inquirer, March 27, 1972.

25. Although diversion projects are aimed at rehabilitation and not at ensuring appearance at trial, they are considered here because they represent an alternative to pretrial detention.

26. In New Haven, the Diversion of Offenders Project is designed to select out accused offenders who are likely to respond to short term, minimum intervention rehabilitative services focusing primarily on job training and job placement. City of New Haven, Diversion of Offenders Grant Application 2, March 27, 1972.

In Washington's Project Crossroads a potential participant must be not only a first offender but also: (1) between the ages of 16 and 26; (2) a resident of the Washington, D.C., area; (3) unemployed, underemployed, or a school dropout; (4) charged with specified nonviolent crimes; and (5) qualified for personal recognizance pretrial release under the criteria of the D.C. Bail Agency. All drug addicts and alcoholics are excluded. Nationil Commission for Children and Youth, Project Crossroads 2-3 (1971) [here. inafter cited as Project Crossroads]. 
the accused receives counseling, social services, job referral, or training. ${ }^{27}$ If the accused performs adequately, his case may be nolled by the prosecutor or dismissed by the court. ${ }^{28}$

\section{e. Bail review}

Efforts have been made to require periodic review by courts of the bail conditions of pretrial detainees in light of new developments in the case, new information about the defendant's background, and the amount of time the defendant has already spent in jail. In the federal system a defendant has the right to review by the bail setter, upon request, 24 hours after the imposition of release conditions he cannot meet. ${ }^{20}$ The Federal Rules of Criminal Procedure also require that a jail inventory be prepared biweekly by the prosecutor and presented to the court. ${ }^{30}$

\section{Multiple Projects}

Single project reforms have shown that the availability of additional information and alternatives can improve pretrial status decisions. No one of these projects, however, can be used by all pretrial defendants. Some jurisdictions have responded to this problem by implementing more than one of these reforms and have discovered that the number of defendants placed under less restrictive pretrial conditions has increased while the failure to appear rate and the cost factor have remained acceptable. ${ }^{31}$

Jurisdictions employing a multiplicity of such pretrial projects, however, encounter additional difficulties which suggest that broader reform is necessary. Typically, the individual pretrial projects merely

27. See, e.g., City of New Haven, Diversion of Offenders Grant Application 8C, March 27, 1972; Vera Institute of Justice, The Manhattan Court Employment Project, Summary Rerort on Phase One: Nov. 1, 1967-Ocl: 3, 1969, at 2 (1970); Projecr Crossroads, supra note 26, at 11-33.

28. Sixty-two percent of the 750 defendants who had completed the Project Crossroads program by September 1970 had charges against them dismissed. Project CrossROADS 33.

29. 18 U.S.C. $\$ 3146(d)(1970)$. He also has a right to a written statement by the judicial officer of reasons for setting conditions that result in detention. Id. If he is still detained and the conditions were set by a judicial officer other than a judge, he may move the court having original jurisdiction over his offense to amend the con. ditions. If this motion is denied, or if the original conditions were set by a judge, he may appeal to the appellate court having jurisdiction. Id. $\$ 3147$.

30. See Fed. R. Crim. P. 46(h).

31. In Des Moines, Iowa, a supervised release program supplementing an ROR project achieved the release of more defendants while maintaining a very low skip rate. See note 19 supra. Another example is the Connecticut Bail Commission, which secures the release of defendants not covered by local programs that may exist. See note 12 supra. 
obtain the release of those defendants who satisfy their criteria and reject the rest, passing on the responsibility for such detainees without, in most cases, transmitting the valuable information which was obtained about them. No single authority follows the defendant through the pretrial process and adjusts his status as necessary. Funding is obtained by each program without regard for the problems of the system as a whole. Such problems, and others created by piecemeal reform, are illustrated by the operation of the pretrial system in New Haven, Connecticut.

New Haven has a citation release program conducted by the police, ${ }^{32}$ a stationhouse ROR program, ${ }^{33}$ a state Bail Commission, ${ }^{34}$ a diversion project, ${ }^{35}$ and a Redirection Center at the local jail. ${ }^{36}$ In the initial and subsequent status decisionmaking areas, however, the separate administration of these reform programs does not facilitate efficient information gathering and use of the most advantageous alternatives at acceptable costs. There is inadequate sharing of information as the defendant moves through the process. ${ }^{37}$ There is little feedback of data from projects later in that process that would aid either in rectifying incorrect status decisions or in suggesting procedural changes for earlier programs. ${ }^{38}$ Even if there

32. During the citation release program's first year in New Haven (Oct. 1, 1970, through Sept. 30, 1971), citations were issued after 6.9 percent of the 9,937 arrests. Berger, supra note 10 , at 405.

33. All arrestees who do not qualify for citation release are brought to the police detention facility and given a bail interview, which may be waived. New Haven Department of Police Services General Order 71-4, at 4, April 22, 1971. The police determine whether to release them on their own recognizance based upon an assessment of family ties, residence, and employment record. Id. at 4-5. Of the 9,937 misdemeanants arrested during the first year of operations, see note 32 supra, 24.0 percent were released on their own recognizance at the stationhouse. Berger, supra note 10, at 405 . Thus, taking citation release into account, a total of 30.9 percent of all misdemeanants were released by the police without bail before trial.

34. In 1971-72, the Bail Commission conducted 4,703 interviews in New Haven. Annual Report of the Chief Bail Commissioner, supra note 13, at chart 1 . The bond was unchanged in 69 percent of the cases, lowered in 5 percent, and raised in less than 1 percent. The other 26 percent were released on a written promise to appear or on a nonsurety bond. $I d$. at chart 2.

35. See note 26 supra.

36. The Redirection Center is a federally-funded pretrial project at the New Haven Correctional Center designed primarily to help detainees improve their pretrial status. In addition to serving as a link to programs that might lead to release, the Center provides limited counseling services to those detainees who remain in detention. Redirection Center Report, supra note 2, at 5, 6 .

37. The interview form used at the stationhouse ROR stage is passed on to the Bail Commissioner if the defendant is not released. If the defendant continues to remain in custody, however, the form is not sent to the Redirection Center at the jail but is filed at the Bail Commission office. Interview with Thomas O'Rourke, Chief Bail Commissioner, Connecticut Bail Commission, Oct. I, 1973 [hereinafter cited as O'Rourke Interview].

38. Thus, although the Redirection Center is in a position to review the decisions made by the Bail Commissioners and rectify individual mistakes, it takes the position that it is not its function to suggest procedural changes, such as additions to the 
were feedback, no single person has authority to force beneficial changes on other separately administered projects. Moreover, at no point in the status decision process does a decisionmaker have before him a comprehensive presentation of all available alternatives. ${ }^{36}$

The multiple reforms in New Haven have also raised new problems concerning the allocation of resources. The task in this regard is clear: The needs of the system of pretrial alternatives must be accurately assessed; priorities must be set and plans must be made based upon those needs; resources must be allocated accordingly; and there must be sufficient flexibility to permit the shifting of resources as needs change. However, there is little communication among the elements of the disorganized New Haven pretrial process, ${ }^{40}$ with the inevitable consequence that the overall needs of the spectrum of alternatives never receive adequate consideration. Gaps and overlaps in functions are evidence that priorities and plans are not coordinated. ${ }^{41}$ Since these various projects have no single fundor, no one is able to reconcile their separate and uncoordinated resource requests. ${ }^{42}$ Separate administration and funding also preclude the possibility of shifting resources from one project to another when necessary. ${ }^{43}$

interview form, which might avoid future mistakes. Interview with Dennis Guay, Director, New Haven Redirection Center, August 17, 1973 [hereinafter citcd as Guay Interview]. The diversion project is in a similar review position with respect to the Bail Commissioners, but its staff also does not suggest changes in Bail Commission procedures which might improve status decisions. Interview with Danicl Ryan, Director of New Haven Pretrial Services Council, August 17, 1973 [hereinafter cited as Ryan Interview].

39. At the time the Bail Commissioner makes his initial status recommendation, the staff of no other pretrial program has had a chance to interview the defendant. O'Rourke Interview, supra note 37. Since the Commissioner's recommendation could include the imposition of conditional release, several potentially important conditions, such as enrollment in drug or alcohol treatment programs, are not considered. Similarly, a subsequent status decision made to correct an initial error may not involve a consideration of all alternatives. Thus, when the Redirection Center recommends to the court that a defendant be released from jail, the Bail Commission is neither consulted nor utilized as a possible release alternative. Guay Interview, supra note 38 .

40. The director of the New Haven Pretrial Services Council, however, noted that the Council was created in response to a perceived problem of little or no communication among the elements of the pretrial process. Ryan Interview, supra note 38.

41. Gaps in the presentation of alternatives to the decisionmaker were notcd at note 39 supra. In addition, since the Bail Commission interview form is not passid on to the Redirection Center at the jail, see note 37 supra, the Redirection staff must duplicate efforts already made. Guay Interview, supra note 38.

42. The police are funded by the city with the aid of Law Enforcement Assistance Administration (LEA.A) funds, the Bail Commission is funded by the state legislature (sec O'Rourke \& Carter, supra note 12, at 516), the diversion project is funded by an LE.AA grant (see note 26 supra), and the Redirection Center is funded by another LEAA grant (see Redirection Center Report, supra note 2).

43. The experience of the District of Columbia Bail Agency, see pp. 166.67 infra, indicates that the Bail Commission is an excellent point at which a conditional relcase program could be implemented. Due to lack of funds necessary to adequately super: vise compliance with conditions, however, conditional release is seldom resorted to 


\section{Response to the Problems of Piecemeal Reform}

Faced with the problems described above, several jurisdictions have attempted to coordinate some of the functions of normally isolated programs. These coordination efforts can be classified as either limited or comprehensive. The limited efforts focus largely on resource allocation and are only advisory with respect to the provision and management of information and alternatives at the status decision stages. More comprehensive coordination of pretrial status alternatives has occurred in those jurisdictions that have created pretrial agencies to deal authoritatively not only with resource allocation but also with problems at the initial and subsequent status determination stages as well.

\section{A. Limited Coordination}

The most common approach to the problems of lack of coordination and fragmentation of responsibility throughout the entire criminal justice system ${ }^{44}$ has been the formation of criminal justice coordinating councils. The first was formed by the Mayor of New York City in $1967^{45}$ in response to a recommendation of the President's Commission on Law Enforcement and Administration of Justice. ${ }^{40}$ Composed primarily of representatives from most of the public agencies which deal with the criminal justice system and its problems, councils of this type often also have representatives of other segments of the community, including business, labor, and service organizations. ${ }^{47}$

by the Bail Commissioners. O'Rourke Interview, supra note 37. The Redirection Center, on the other hand, at a much later point in the system, is beginning to implement its own supervised release program with LEAA funds. Guay Interview, supra note 38. Since these projects are separately administered, there is no possibility that the funds could be shifted to the earlier stage of the process.

44. See Morris \& Van Kessel, San Francisco Criminal Justice Project, 58 A.B.A.J. 263 (1972); Newman \& Swceney, Catalysts for Criminal Justice Reform: The Cleveland Experience, 2 URB. LAw. 518, 523 (1970)

45. New York Criminal Justice Coordinating Council, 1972 Criminal Justice Plan ii (1972) [hereinafter cited as 1972 N.Y. PLAN].

46. Presideñ's Commission on Law Enforcenient and Administration of Justice, Thie Cilillenge of Crime in a Free Society 280 (1967).

47. See 1972 N.Y. PLiN, supra note 45 , at ii; Newman \&. Sweency, supra note 44, at 524. A variant of the criminal justice coordinating council is the New Haven Pretrial Services Council, the first organization consisting of representatives of elements of the criminal justice system formed specifically to deal with the problems of the pretrial system. The members of the Council include representatives of the New Haven Department of Police Services, the Office of the Prosecutor and the Public Defender for the Sixth Circuit, the New Haven Legal Assistance Association, and the Yale Law School, as well as the Chief Bail Commissioner and the Chief Clerk of the Circuit Courts. City of New Haven Action Grant Application, New Haven Pretrial Services Council 2 (1971). 
Though these councils serve some useful purposes, their capacity for improving the pretrial decisionmaking process is limited. They commission studies, submit grant applications, provide a useful forum for discussion of pretrial problems, and even operate some projects, ${ }^{4 \mathrm{~s}}$ but their authority over the other projects is limited to recommending internal procedural and resource allocation priorities. ${ }^{49}$ With no administrative control of their independent members, they lack authority to institute procedural changes that might improve information passage and feedback and comprehensive alternative presentation. Furthermore, since the coordinating councils officially allocate only incremental Law Enforcement Assistance Administration funds, their impact even in the allocation area is slight. ${ }^{50}$

\section{B. Comprehensive Coordination}

An approach which offers more promise is that of the comprehensive pretrial agency. At present, only two such agencies exist. ${ }^{51}$ In 1971 the Common Pleas and Municipal Court of the City of Philadelphia established a Pre-Trial Services Division ${ }^{52}$ which is responsible for the appearance in court of all releasees without regard to the method of their release. The Division has direct administrative control over an ROR project ${ }^{53}$ and a 10 percent cash bail program. It also cooperates with the staffs of several other pretrial programs. ${ }^{54}$ Though it lacks a 10 percent cash bail project, the District

48. The New Haven Pretrial Services Council, supra note 47, initiated the New Haven Diversion of Offenders Project. See note 26 supra.

49. Ryan Interview, supra note 38 .

50. 1972 N.Y. PLAN, supra note 45 , at 180. Since enactment of the Omnibus Crime Control and Safe Streets Act of 1968, 42 U.S.C. $\$ \$ 3731-37$ (1970), the coordinating councils have frequently been employed as the planning bodies that are required by the Act as a precondition to the receipt of funds from LEAA. See, e.g., 1972 N.Y. Plan, supra note 45, at ii; Newman \& Sweeney, supra note 44, at 525.

51. A comparable organization, the Polk County (Des Moines) Department of Court Services, will not be included in this discussion because it deals with convicted as well as pretrial defendants. See A Description of the Functions and Procedures of the Polk County Department of Court Services, March 1972.

52. The Division is funded by grants from LEAA and by the city of Philadelphia.

53. Each ROR releasee is subject to the Division's supervision, and failure to cooperate with the ROR program may result in his arrest and incarceration. Philadelphia Common Pleas and Municipal Court Pre-Trial Services Division, Operational Phases of the ROR Program 2 (1972). Each must also report to the Division's notification section. In turn, the section reminds the defendant of his court date. Interview with David J. Lester, former Director of the Philadelphia Common Pleas and Municipal Court Pre-Trial Services Division, in Philadelphia, Pa., June 30, 1972 [hereinafter cited as Lester Interview].

54. The Division cooperates with the Pennsylvania Program for Women and Girl Offenders, the Pre-Trial Diversion Program, and the City Drug Program. Philadelphia Common Pleas and Municipal Court, Application for Subgrant, 10\% Cash Bail Program, 1971. 
of Columbia Bail Agency ${ }^{55}$ also has a wide range of responsibilities, ${ }^{56}$ including supervision of ROR and conditional release programs, exploration of pretrial rehabilitation alternatives, and coordination with the police citation program. Both agencies have succeeded in increasing the numbers of persons granted pretrial release at acceptable failure to appear rates. 57

While these two agencies are not without faults, their authoritative supervision of subordinate individual projects has resolved a number of the problems associated with uncoordinated administration. Progress has been particularly noticeable with respect to information flow and use of alternative dispositions. First, improved use is made of internally-developed information as the defendant moves through the process. The Philadelphia Pre-Trial Services Division obtains background data on each defendant within hours of his first contact with the system. ${ }^{58}$ On the basis of this information it decides whether or not to recommend release on own recognizance. ${ }^{50}$ If $\mathrm{ROR}$ is denied by the judge, the information is passed

55. In 1963 the Ford Foundation granted funds to Georgetown University to institute a three year experimental bail program. McCarthy \& Wahl, supra note 6. This project led to the establishment by Congress of the District of Columbia Bail Agency in 1966. The Agency is under the allthority of an executive committee composed of the chief judges of the United States Court of Appeals for the District of Columbia Circuit, the United States District Court for the District of Columbia, the District of Columbia Court of Appeals, the Superior Court, and a fifth member selected by the chief judges. A director appointed by the executive committee is responsible for day-to-day operations.

56. These responsibilities include the formulation of pretrial release conditions, the provision of notice to releasees of court appearances, the supervision of compliance with conditions of release, as well as the assistance of releasees in securing medical, social, and employment services. D.C. BAIL AGENCY HANDBook, supra note 18, at 1 .

57. During the first seven months of the Philadelphia project's operation there were a total of 11,361 court appearances scheduled for ROR releasees, of whom 7.1 percent or 802 failed to appear. The rate of nonappearance of those released on the basis of Division ROR recommendations was 5.8 percent. The rate of nonappearance of those not recommended by the Division but granted ROR anyway was 22.7 percent. Philadelphia Common Pleas and Municipal Court Application for Subgrant, ROR Program, 1972.

In the District of Columbia in 1963, the year before the D.C. Bail Project began operation, 2.5 percent of the defendants were released on personal recognizance or other nonfinancial conditions. In 1965, at the peak of the Project's Operation, 20.2 percent of the defendants were similarly released with a failure to appear rate of 3 percent. R. Molleur, supra note 2, at 90-9I. In 1970, when the D.C. Bail Agency was established and began coordinating the functions noted in the text, the release rate for similarly situated accuseds climbed to 57 percent with a failure to appear rate of 2.8 percent. District of Columia BaIL Agency, REPORT of THE District of Columbia Bail Agencr for the Period January 1, 1970-December 31, 1970, at 3-4 (1971) [hereinafter cited as 1970 REPORT].

58. All defendants are interviewed by ROR staff members soon after they are brought to the central police facility for booking. Lester Interview, supra note 53 .

59. The recommendation is made to the judge before whom the defendant first appears. Since the criminal division is in session 24 hours a day, this first appearance usually occurs within a few hours of the arrest. During the first 17 months (June 1 , 1971-Oct. 31, 1972) of the ROR project's operation, 50,633 defendants were interviewed; 24,021 or 47.4 percent were recommended for release on their own recogni- 
along to the 10 percent cash bail project. Within 48 hours the information given by those not released ROR and unable to post 10 percent bond is verified. If the Division feels that the defendant should either be released or should have his bail reduced, a petition for bail reduction is prepared and presented to a judge. ${ }^{60}$

Second, feedback and exchange of information among different parts of the agency has led to a number of procedural improvements. ${ }^{61}$ The Philadelphia Pre-Trial Services Division has the responsibility for rearresting those releasees who fail to appear in court, ${ }^{62}$ a duty performed by the police in all other jurisdictions. The rearrest unit found that locating defendants who had moved recently or who had no fixed address was a difficult task. Because of the direct administrative ties between this unit and other elements of the pretrial status decisionmaking process, however, this difficulty received prompt attention leading to changes at the initial interview. In addition to the present address of the defendant, the interviewer asks as well what locations he frequents or where he "hangs out." The defendant's response provides the unit additional information concerning locations in which to search for the accused..$^{.3}$

Third, at both the initial and subsequent decision stages there is a relatively comprehensive presentation of available alternatives to the decisionmaker. In the District of Columbia, the Bail Agency

zance and 14,443 or 60.1 percent of those recommended were granted ROR. Another 3,497 defendants who were not recommended were granted ROR. An additional 1,127 defendants were granted release through a supplementary ROR petitioning process. See note 60 infra. Pre-Trial Services Division, ROR Program Statistics, 1972.

60. During the period June 1, 1971-Oct. 31, 1972, 2,283 petitions were preparcd. As a result, 1,127 defendants were granted ROR, 867 had their bail reduced, 20 who initially had been denied bail had bail set, and 269 petitions were denied. Id.

61. The present director of the Philadelphia Pre-Trial Services Division believes that procedural improvements are only made possible by consolidated administration of pretrial tasks. As an example he noted that initial interviewers, because of their limited tasks, often have a lack of appreciation of the impact of their efforts on the rest of the pretrial process. In order to effect changes in the procedures at this stage, it is therefore necessary to have an administrative structure that can recognize the problems later in the system and impose changes on the earlier stages. Interview with Dewaine L. Gedney, Jr., Director of the Philadelphia Common Pleas and Municipal Court Pretrial Services Division, September 24, 1973 [hereinafter cited as Gedney Interview].

62. The rearrest capability exists for two reasons. First, the Division feels it has a responsibility for those persons under its supervision. It does not believe that another atthority, such as the police, should be burdened with its mistakes. Lester Interview, supra note 53. Second, the Division feels that, because its officials are generally viewed by a community as less threatening than the police, it can better apprehend fugitives than can the police. Gedney Interview, supra note 61.

63. Gedney Interview, supra note 61. Similarly, when the Washington, D.C., Bail Agency's notification division found that addresses were often incorrectly entered on the initial interview form, the form was changed to require interviewers to enter the ad. dress in two places. Interview with Bruce Beaudin, Executive Director, Washington, D.C., Bail Agency, September 25, 1973 [hereinafter cited as Beaudin Interview]. 
is able to consider all alternatives simultaneously before making a recommendation to the court, rather than considering a defendant for ROR initially and for conditional release at a later date. ${ }^{64}$ If a violation in the initial conditions of release is subsequently discovered, it is reported to the court. ${ }^{65}$ Rather than leave the judge with no alternative at this point other than money bail, the Agency presents to the court all the information it has available concerning the defendant and the violation, sometimes recommending modified conditions of release. ${ }^{.0}$

The agencies are also capable of doing a better job of allocating resources and setting priorities. First, since information circulates freely within the agencies, they are able to assess the relative needs of a wider range of pretrial functions and alternatives than any decisionmaker could before and can thus in a single budget request set priorities based on those needs. Second, the agencies are able to shift funds and other resources from one use to another in order to meet changing circumstances. For example, during the 1971 May Day demonstrations in Washington, D.C., that resulted in mass arrests, the Bail Agency shifted its staff heavily into the initial interviewing stage to meet the overload. ${ }^{67}$

These agencies do not, of course, escape criticism. The complaints that have been made, however, focus on problems that are the result of inadequate funding and staff rather than organizational structure. ${ }^{\text {os }}$

Although these agencies consolidate and coordinate a significant number of the pretrial status alternatives, they would nevertheless

64. For a discussion of the criteria for recommendations for each alternative see D.C. BAIL Agency HaNdBook, supra note 18, at 93-107.

65. At any one time there are approximately 3,500 persons awaiting trial in the District of Columbia. The Agency must stpervise approximately 10,000 conditions which have been imposed on those defendants. Id. at 42 . Supervision is accomplished by telephoning employers, homes, narcotics testing facilities, and similar sources of information about the accuseds' behavior while awaiting trial. The Agency also receives reports from such third party custodians as Bonabond, Blackman's Development Center, and the Narcotic Treatment Administration. 1970 REPoRT, supra note 57, at 5 . Between June 1, 1970, and December 31, 1970, 1,123 violations were reported to the court and the United States Attorney. Id. at 6.

66. D.C. BAIL AGENCY HANDBook, supra note 18 , at 109.

67. Beaudin Interview, supra note 63. The Bail Agency has also shifted funds in reaction to criticism of its release criteria and decisions. Because of public concern with recidivism, a new section in the Agency was created to attempt to identify rearrested persons at the time of the initial interview. Id.

68. References to the inadequate funding and staff of the D.C. Bail Agency are numerotis. Among them are National Comission on THE Causes and Prevention of Violence, The Rule of LAw: AN Alternative to VIOLENCE 444, 445, 447 (1970); URBan Research Corporation, Preventive Detention 69, 93 (1971); Hearings on the Bail Reform Act of 1966 Before the Subcomm. on Constitutional Rights of the Senate Comm. on the Judiciary, 91st Cong., Ist Sess. 30, 33-34, 201-02, 203, 334 (1969). 
seem to be only intermediate steps in the proper direction. Many alternatives that should be included, such as diversion, drug and alcohol treatment, and counseling services, are not within their planning and administrative structure. More important, control of one major status alternative-incarceration-has yet to be recognized as a potentially useful addition to any comprehensive pretrial organization.

\section{The Next Step: Inclusion of Pretrial Detention}

The District of Columbia Bail Agency and the Philadelphia PreTrial Services Division have demonstrated the potential effectiveness and practicality of establishing a single administrative structure for the coordination of pretrial programs. However, neither they nor any of the more limited reforms described above have had a significant impact upon a pretrial status alternative which affects a substantial number of criminal defendants: detention itself. Although detention is not normally considered by commentators to be a part of the pretrial spectrum, ${ }^{69}$ recent trends in constitutional law may force a reappraisal of the detention alternative and lend support to the conclusion that pretrial detention should also be placed under the exclusive control of a unified pretrial agency.

69. An examination of the literature dealing with the administration of the criminal justice system discloses the absence of attention directed toward the pretrial detention area. See, e.g., Contemporary Studies Project, Perspectives on the Administration of Criminal Justice in Iowa, 57 IowA L. REv. 598 (1972). In this detailed analysis of the Iowa criminal justice system, the subject of detention is only briefly mentioned in the general context of pretrial delay. $I d$. at 715 . The criminal justice system is sometime: referred to simply as "police-courts-corrections," and only the primary function and problems of those areas are discussed. See WEston, Supervision IN THE Administration of Justice-Police, Correcrions, Courts (1965); Gilmore, Reflection on the Administration of Criminal Justice, 50 Mrch. ST. B.J. 370 (1971). Even those articles which call for either less sharply defined administrative boundaries or more coordination in the criminal justice system seldom mention pretrial detention. See Gilmore, supra. Those materials that mention pretrial detention typically give it little space. Murphy, Cooperation in the Criminal Justice System, 18 CRIME \& DeLIN. 42 (1972); Ruth, Promoting Consistent Policy in the Criminal Justice Process, 53 VA. L. REv. 1489 (1967). See President's Commission on LAW Enforcement and THE AdMinistration of Justice, The Challenge of Crime in A Free Societr 178 (1967) (one paragraph on pretrial detention); E. Powers, The Basic Structure of Criminat Justice in Massichusetrs 94 (1968) (two paragraphs mention pretrial detention).

Articles which deal directly with pretrial detention have usually focused on the physical conditions in the jails, seldom discussing any larger implications. See, e.g., Richmond, The Jail blight, 11 CRIME \& DELIN. 132, 133 (1965). The most notable exception is the recent Note, Constitutional Limitations on the Conditions of Pretrial Detention, 79 YALE L.J. 941 (1970) [hereinafter cited as Conditions of Pretrial Detention]. Other examples of increased attention toward some of the implications of the problems of pretrial detention are TASK FORCE REPORT: CoRRECTIONs, supra note 2; McGee, Our Sick Jails, 35 FEd. Prod. 3 (1971); Survey, Local Adult Correctional Institutions and Jails, 13 CRIME \& Delin. 137 (1967). 


\section{A. The Present Situation}

The nation's jails are locally administered in all but three states. ${ }^{70}$ The administrator is usually a member of a law enforcement unit, the board of commissioners, or the corrections department. ${ }^{11}$

The conditions under which pretrial detainees are presently housed are unacceptable for two reasons. First, the physical condition of detention facilities across the country is notoriously poor, ${ }^{72}$ primarily because of lack of political power of and public interest in the criminal accused. But second, and more important, in every state pretrial detainees are confined in the same facility with and under essentially the same conditions as convicted prisoners. ${ }^{73}$ This condition may be said to be the function of a basic misunderstanding of the constitutional status of the pretrial detainee.

Several recent court decisions have held that the rights of a pretrial detainee must be determined with reference to the class of defendants released on bail rather than the class of convicted prisoners. ${ }^{74}$ On the basis of these rights the courts have called for the

70. Those states are Connecticut, Delaware, and Rhode Island. U.S. DEP'T oF Justice, L.E.A.A., 1970 National JAIL Census 9 (1971) [hereinafter cited as 1970 JaIL Census].

71. See TAsk Force Report: Corrections, supra note 2, at 79; E. Powers, supra note 69, at 9I; McGee, supra note 69, at 5-6. Richmond, supra note 69, at 133 .

72. The typical county jail has been described as "the lowest form of social institution on the American scene." McGee, The Administration of Justice: The Correctional Process, 5 N.P.P.A.J. 225, 228 (1959). Twenty-five percent of all jail cells are in buildings more than fifty years old; 5.5 percent are in buildings more than one hundred years old. 1970 JAIL CeNsus, supra note 70 , at 1 . Eighty-six percent of those jails that are county level or located in municipalities of 25,000 or greater population have no recreation facilities; almost 90 percent have no educational facilities; 50 percent have no medical facilities; 25 percent have no visiting facilities; 1.4 percent are without cven an operating flush toilet. Id. For further discussion of conditions in the nation's jails see W. Nagel, The New Red Barn: A Critical Look at THE Modern American P'RISON 17-35 (1973); TASK FORCE REPORT: CORRECIIONS, supra note 2, at 4, 24-25; Con. ditions of Pretrial Detention, supra note 69, at 942-47; Note, Pretrial Detention in the New York City Jails, 7 Colum. J.L. \& Soc. Pros. 350, 354-65 (1971) [hereinafter cited as New York City Jails]. Note, Nebraska Jails: Cure or Cause?, 49 NEB. L.J. 71 (1969). On the conditions in specific jails see, e.g., Taylor v. Sterrett, 344 F. Supp. 411, 412-16 (N.D. Tex. 1972); Brenneman v. Madigan, 343 F. Supp. 128, 133-35 (N.D. Cal. 1972); Hamilton v. Shiro, 338 F. Supp. 1016 (E.D. La. 1972); Hamilton v. Love, 328 F. Supp. 1182, 1184, $1188-90$ (E.D. Ark. 1971); Jones v. Wittenburg, 323 F. Supp. 93, 95-98, 99 (N.D. Ohio 1971), aff'd sub nom. Jones v. Metzger, 456 F.2d 854 (6th Cir. 1972).

73. The 1970 Jail Census indicates no exceptions. 1970 JaIL Census, supra note 70, at 2-3, 9-19.

74. Using an equal protection analysis, courts have rejected the classification of detainees with convicted prisoners:

Under the equal protection clause it would not seem possible to be able to classify detainees, awaiting trial, in the same group with those persons who have bccil convicted of crime and sentenced to prison. And yet that appears to be what we have been doing as a practical matter, not only locally, but across the nation. Hamilton v. Love, 328 F. Supp. 1182, 1191 (E.D. Ark. 1971). Instead, detainees have
been classified with bailees:

The constitutional authority for the state to distinguish between criminal de- 


\section{elimination, often without regard to $\operatorname{cost}^{75}$ of unreasonable deten- tion conditions that could be said to constitute "punishment."70}

fendants by frecing those who supply bail pending trial and confining those who do not, furnishes no justification for any additional inequality of treatment beyond that which is inherent in the confinement itself.

Butler v. Crumlish, 229 F. Supp. 565, 567 (E.D. Pa. 1964). As the court noted in Brenneman v. Madigan, 343 F. Supp. 128 (N.D. Cal. 1972), any action toward both bailees and detainees must be reasonably xelated to the legitimate state interent in ensuring their appearance at trial. Id. at 138 . It further argued that the principle of Griffin v. Illinois, $35 \mathrm{~L}$ U.S. 12 (1956), makes unconstitutional any incursions on the rights of a pretrial detaince other than those arising from the need for custody, instead of bail, to ensure his presence at trial. Any restriction or deprisation of those rights, beyond those which inhere in the confinement itself, must be justified by a compelling necessity arising from a lack of alternatives. Sec Seale v. Manson, 326 F. Supp. 1375 (D. Conn. 1971) (rule on mustaches and beards not validly based on sani* tation or other requirements); Christman v. Skinner, 323 N.Y.S.2d 767,769 , 67 MIisc. 2d 232, 234 (Sup. Ct. 1971), rev'd on other grounds, 329 N.Y.S.2d 114 (.1pp. Div. 1972) ("[n]othing in the record justifies the assumption that the presence or absence of a mustache or beard has any reasonable connection with the appearance or non-appearance of plaintiff, an 'unconvicted detaince,' at trial").

One court has taken a further step under the equal protection doctrine and $a:$ pressly classified detainces with all free citizens. See Tyler v. Ciconc, 299 F. Supp. 684 (W.D. Mo. 1969) (regulations requiring permission for the preparation of inanuscripts, setting maximum word length, restricting circulation, and prohibiting negotiations for publication held invalid as applied to pretrial detainees).

75. All of the changes described in note 76 infra have been ordered in spite of official insistence that they would either cost more money than was available or generate too much work for the jail staff. The most influential and far-reaching decision in this area has been Hamilton v. Love, 328 F. Supp. 1182 (E.D. Ark. 1971): Inadequate resources can never be an adequate justification for the state's de. priving any person of his constitutional rights. If the state cannot obtain the resources to detain persons awaiting trial in accordance with minimum constitutional standards, then the state simply will not be permitted to detain such persons. The final decision may, indeed, rest with the qualified voters of the governmental unit involved. This court, of course, cannot require the voters to make available the resources needed by public officials to meet constitutional standards, but it can and must require the release of persons held under con. ditions which violate their constitutional rights, at least where the correction of such conditions is not brought about within a reasonable time.

Id. at 1194. This statement has recently been quoted with approval in both Brenneman v. Madigan, 343 F. Supp. 128, 139 (N.D. Cal. 1972), and Taylor v. Sterrett, 344 F. Supp. 411, 422 (N.D. Tex. 1972.) See also Rozecki v. Gatghan, 459 F.2d 6 (Ist Cir. 1972): Hamilton v. Landriett, 351 F. Supp. 549 (E.D. La. 1972); Conklin v. Hancock, 334 I. Supp. 1119,1122 (D.N.H. 1971).

76. This conclusion has been reached by coupling a due process argument with the equal protection analysis discussed in note 74 supra. That is, since all pretrial defendants are presumed innocent and are classified with all other innocent persons, due process forbids the state to punish them prior to conviction. The principle has long been recognized:

[This] imprisonment, as has been said, is only for safe custody, and not for punishment; therefore, in this dubious interval between commitment and trial, a prisoner ought to be used with the utmost humanity; and neither be loaded with needless fetters, nor subjected to other hardships than such as are absolutely requisite for the purpose of confinement only.

4 W. Blackstone, Commentaries 300 (1765). However, only quite recently has this concept had constitutional application:

Having been convicted of no crime, the detainces should not have to suffer any punishment, whether "cruel and unusual" or not.

...

If the conditions of detainment are such that they can only be considered punitive, or as punishment, then, of course, the subjecting of such detainees to stich conditions would violate the due process requirements of the Fifth and Fourtcenth Amendments, as well as the quoted provision of the Eighth Amendment. 
These decisions point toward the further conclusion that integration of pretrial detainees and convicted prisoners may itself be unreasonable, and hence physical separation, even if in the same building, may be constitutionally required. ${ }^{77}$ Separate treatment and even complete segregation could be carried out by present detention facility administrators, but a more fundamental reorganization might be of greater benefit to both the defendant and the pretrial process.

\section{B. Inclusion of Detention in the Pretrial Agency}

Pretrial detention could be placed under the control of the suggested pretrial agency, ${ }^{\text {is }}$ thus giving it responsibility for all unconvicted defendants. Such physical separation and independent administration of pretrial and convicted prisoners raise, however, the question of inordinate expense. ${ }^{79}$ Although the cost could be minimized by simply isolating the pretrial and convicted populations within one facility (by placing them in different wings, for example), in many situations two physically separated structures may be necessitated by administrative convenience and the disparity between the condi-

See Hamilton v. Love, 328 F. Supp. 1182, 1191, 1193 (E.D. Ark. 1971). For example, institutional regulations governing detainees must not be grounded on punishment. See, c.s., Wayne County Jail Inmates v. Wayne County Board of Commissioners, No. 173217 (Mich. Cir. Ct. May 25, 1971), 5 CleAringhouse Rev. 108 (1971), quoted in Bass, Correcting the Correctional System: A Responsibility of the Legal Profession, 5 CLEaringnouse REv. 125, I17 (1971). Deterrence and rehabilitation, like punishinent, are illegitimate aims with regard to the detainee. See, e.g., Seale v. Manson, 326 F. Supp. 1375,1379 (D. Conn. 1971).

As a result of challenges by pretrial detainees, courts have ordered extensive modilications in physical facilities and institutional regulations. See, e.g., Taylor v. Sterrett, 34 F. Supp. 411, $422-23$ (N.D. Tex, 1972); Jones v. Wittenberg, 330 F. Supp. 707, 721 (N.D. Ohio 1971); Hamilton v. Love, 328 F. Supp. 1182, 1195-96 (E.D. Ark. 1971); Seale v. Manson, supra at 1375,1379 .

77. Several commentators have specifically suggested separation. See TAsK ForcL Rerort: CoRrectioss, supra note 2, at 24, 168; Conditions of Pretrial Detention, supra note 69 , at 957 . Most courts have only gone as far as stating that detainees and sentenced men cannot be treated alike. See Hamilton v. Love, 328 F. Supp. 1182, 1191 (E.D. Ark. 1971); Jones v. Wittenberg, 323 F. Supp. 93, 100 (N.D. Ohio 1971). Detention of pretrial detainees under the same conditions in the same facilities as convicted persons is hardly consonant with this principle. At least one court apparently agrees. In a detailed order for improvement of physical and administrative conditions at a local jail, Judge Christenberry stated:

Prisoners awaiting trial shall be effectively separated from the convicted. If pos-

sible the prisoners awaiting trial should be housed in a separate building.

Hamilton v. Landrieu, 351 F. Stpp. 549, 552 (E.D. La. 1972). Thus, cven if all of the inadequacies in the jail's physical plant were rectified, it would still be necessary to house pretrial detainees separately.

78. In one jurisdiction administration of some convicted persons has been shifted away from corrections and law enforcement. In Polk County (Des Moines), the Department of Court Services administers the minimum security Fort Des Moines Residential Corrections Facility. Oxberger, Revolution in Corrections, 22 DRAKE L. REv. $250,253(1973)$. In no jurisdiction does a pretrial agency administer a pretrial detention facility.

79. See Wilson, New Approaches to Pretrial Detention, 39 J.B.A. KAN. 13, 60 (1970). 
tions appropriate for the two populations. ${ }^{80}$ If this were necessary, shifting of sentenced inmates to a regional or statewide correctional institution $^{\text {s1 }}$ might mitigate the costs. It is also true that much new jail construction and renovation, forced by age ${ }^{8 * 2}$ and increasing numbers, ${ }^{83}$ is presently planned or under way in all parts of the country..$^{\mathrm{s} .}$ Thus, a regional facility for sentenced prisoners and local facilities for pretrial detainees could share the planned appropriations. Moreover, the pretrial agency should be able to provide nondetention alternatives for more defendants, thus decreasing the population demands on present detention facilities. Although there is little doubt that initially there would be some additional cost, this consideration is outweighed by the foreseeable advantages of consolidated administration of all pretrial services.

\section{Initial and Subsequent Status Determinations}

The jail has great potential as an aid in reaching the correct initial status decision and in facilitating the shifting of defendants from one status to another. As the "reject collector" for the entire pretrial status decisionmaking process, the jail should be seen as a unique and presently unused repository of data. ${ }^{55}$ Constant moni-

80. The conclusion reached in Hamilton v. Landrieu, 351 F. Supp. 549, 552 (E.D. La. 1972), implies that even when all the required improvements have been made in the local jail, the pretrial detainees are still entitled to something more-at a minimum, separation from the convicted population. See note 77 supra.

81. Both the National Council on Crime and Delinquency and the President's Commission on Law Enforcement and Administration of Justice have recommended that regional, state-operated facilities replace local institutions for short-term detention of convicted prisoners. TASK FORCE REPORT: CORRECTIONS, supra note 2, at 80; Local Adult Correctional Institutions and Jails, supra note 69, at 155.

82. See 1970 Jall Census, supra note 70, at 4. See also TASk Force Rerorir: CorrecTroNs, supra note 2 , at 166 , in which a survey found 65 percent of examined shortterm institutions to be 25 years of age or older.

83. Across the United States, one in 20 of the local jails are holding more inmates than they were designed to hold. Altogether 205 institutions reported overcrowding, of which $15 \%$ are exceeding their capacity by 10 persons or more. Fourteen institutions, all located in very large metropolitan areas, reported overcrowd. ing in excess of 300 inmates.

1970 Jarl Census, supra note 70, at 4. See also TASK ForCe Report: CoRRections, supro note 2 , at 166 . The aggregate figures on overcrowding may not, however, reveal the entire picture.

Although absolute overcrowding may not occur for a given jail, it is possible for the same jail to be overcrowded in selected quarters. For example, the section of a jail used for adult males may exceed its capacity, but the female or juvenile sections may be under-utilized so that, overall, the facility may or may not be overcrowded.

1970 JaIl CEnsus 4.

84. The 1970 JAIL Census found that a total of $\$ 170,849,000$ in new construction in all states was planned. 1970 JaIL Census 9.

85. A former Director of the Federal Bureau of Prisons made these observations:

Obviously, the jail administrator does not set bail or determine whether a person will be committed to jail for non-payment of a fine. But he is in a position to 
toring of the characteristics of the jail population would reveal the mistakes made by earlier segments of the process, whether through human error or procedural failure. Such information is essential for the improvement of techniques and procedures, thus preventing future mistakes, and for aiding individual defendants, thus rectifying past mistakes.

The elimination of present administrative boundaries could maximize the possible uses of the data collected. The increased sharing of information that could accompany consolidation would help prevent a duplication of effort on the part of the custodians and those seeking alternatives to detention. ${ }^{86}$ Staff from all projects could have greater access to the accused while he is in the facility, ${ }^{87}$ thus increasing the information available for subsequent status decisions. With the creation of a necessary close liaison between the consolidated agency and the judiciary, ${ }^{88}$ the transmission of information to the courts from all segments of the pretrial status decisionmaking process could also be facilitated. ${ }^{80}$

The characteristics of the detention alternative itself might be broadened with a consolidation of pretrial administration. Present nonjail incarceration alternatives, such as in-patient drug treatment, could be closely associated with the traditional detention facility so that transfers among them could be easily effected. ${ }^{90}$ The role

study and compile information on the cumulative effect of bail and fine policies. Frequently, judges, magistrates, county fiscal officers, and others will welcome the data when made available. Good government requires regular reviews of policies and procedures which affect government costs and community services. The jail administrator is in a singularly effective position to present information for the development of more effective methods in the local government's system of criminal justice as reflected in practices relating to fines and bail bonds.

M. Alexander, Jail. Administration 314-15 (1957).

86. Possible issues of privacy and confidentiality may arise in this context. They can be resolved if the agency shares all information gathered within the agency for use in reaching status decisions, but treats it as confidential as to outside inquiries.

87. The problem of gaining access to the detained population, even for a program operating at the jail, was noted in Redirection Center Report, supra note 2, at 15.

88. In the particular context of detention facilities, calls for improved liaison with the courts are common. See, e.g., Local Adult Correctional Institutions and Jails, supra note 69 , at 152 ; Wilson, supra note 79 , at 54 .

89. The District of Columbia Bail Agency has been ordered to provide information concerning all detainees but has been unable to do so because of the hesitance of other agencies, including the Department of Correction, to release the information. D.C. BaIL AGENCY Handbook, supra note 18, at 61-62. The United States Attorney for the District of Columbia also finds the task difficult and consistently fails to provide reports. $I d$. at 62 . This difficulty illustrates the importance of endowing the primary information provider with the means and authority to compel the release of information by other sources.

90. The Director of the New Haven Redirection Center, which is located at the local jail, noted that prior to the creation of the project other pretrial status alternatives, such as drug or alcohol addiction treatment, were not as a practical matter readily available because staff members of these alternative programs failed to make regular visits to the jail to identify potential participants. Redirection Center efforts 
and attitudes of the employees of detention facilities might also be substantially improved. ${ }^{01}$ Moreover, ratlier than engaging in simple "warehousing" of the accused population,92 the staff could actively aid in the gathering and transferring of information.

Unification could also improve the flow of important information going to the defendant. The pretrial agency could assist his attorney in keeping him informed of scheduling developments, such as changes in court dates. His source of information and supervision would remain the same even if his status were changed.

An argument can be made, of course, that the use of agency interviewers at the jail could accomplish the same purposes outlined above without a change in administration. However, the necessity of crossing administrative boundaries could continue to pose an unnecessary obstacle to creating a more efficient decisionmaking process. ${ }^{93}$

\section{Priority and Allocation Decisions}

The funds for the local pretrial process are characteristically split among the traditional components of the criminal justice system: the police, the courts, and the jail. Since these components receive resources from separate fundors, ${ }^{94}$ neither the fundors nor the recipients are able to coordinate funding for the pretrial area in accordance with any perceived priorities. Indeed, it would appear that fundors do not regard the range of pretrial status alternatives as a distinct aspect of the criminal justice system. ${ }^{95}$

have resulted in. more regular visits by representatives of these programs and the Center helps coordinate their activities at the jail. The Center, however, lacks administrative control over these programs and cannot alter the jail's visiting hous and other regulations which may hinder their efficient operation. Guay Interview, supra note 38.

91. Removing detention from corrections or law enforcement administration could encourage more imagination and creative efforts on the part of detention personncl. See Oxberger, supra note 78, at 261-62.

92. See Canlis, The National Sheriff, quoted in McGec, supra note 69, at 3.

93. See note 89 supra.

94. The state usually funds the courts, see, e.g., 1973-1974 Srute of Connecilcur GOVERNOR'S BUDGET REPORT 53I-38 (1973), and may assist in funding local correctional institutions, while city government usually funds the police department and the local jail. The federal government, through the Omnibus Crime Control and Safe Streets Act of 1968 , 42 U.S.C. $\$ \$ 3731-37(1970)$, may fund state or local criminal justice projects.

95. Thus, in Connecticut, the state funds all local correctional centers (jails) through the Department of Correction. Although the description of the task of the Dcpartment contained in the annual state budget is "custody of sentenced or detained adults," 1973-1974 STATE of CONNECTICUT Governor's BUdGET REPORT 505 (1973), no separate allocations of any kind are mentioned. $I d$. at 505.17 . The allocation of detention resources is also adversely affected by the fact that administrators of detention do not adequately distinguish between the two groups. See note 103 infra. 
In those jurisdictions in which a pretrial agency has been introduced to coordinate some parts of the pretrial process, the jail remains a separate entity. However, the important contribution which close jail and agency interaction can make to the improvement of the pretrial status decisionmaking process $^{96}$ suggests that jail and agency budget requests should be coordinated. When the agency and jail are located in separate bureaucracies, this task is made unnecessarily difficult. If they are funded by separate sources, it is doubtful that the interactions between them will be reflected in budgeting decisions. Thus, the fact that successful pretrial release alternatives are less expensive than detention or that these alternatives may in fact reduce the number of inmates in jail, thereby lowering its costs, may have little impact on budget requests or resource allocation.

In contrast, administrative consolidation of all pretrial status alternatives would create one voice to speak to fundors concerning the needs of the entire system of alternatives, including detention. This would not necessarily mean, of course, that resources within that system as a whole or in any particular segment would increase, but rather that funding could more closely reflect relative priorities with regard to the judicially-mandated distinct class of pretrial defendants. Since this single agency could make more efficient use of pretrial information and alternatives, its budget requests could coordinate overall priorities with actual needs.

Once funds were allocated, unification could permit their more efficient use. Duplication of effort within the pretrial status decisionmaking process might be easier to minimize if policies and procedures were centrally determined. In response to sudden changes in other areas of the criminal justice system, e.g., police arrest policies or court timetables, the agency head could direct an internal reallocation of resources to meet the altered needs of the affected pretrial areas.

\section{Further Implications of a Pretrial Agency}

This Note has proposed one possible approach to comprehensive reform of the pretrial status decisionmaking process: unification and central administration of its many parts. A jurisdiction which adopted this approach would have to resolve two secondary issues. First, what

96. See note 85 supra. 
would be the limits of the agency's decisionmaking authority? Second, where within the criminal justice system would it be located?

\section{A. The Pretrial Agency as Decisionmaker}

Authority for reaching pretrial status decisions in some jurisdictions does not rest completely with judicial officers. The police, through citation and stationhouse ROR programs, and other officials have been given such power. ${ }^{97} \mathrm{~A}$ unified pretrial agency, which would include all status alternatives except citation release, would function most efficiently if it had similar but more extensive authority to render all pretrial status decisions.

Presumably both a judge and an official of the agency would reach much the same initial conclusion if each were presented the same full range of information and alternatives. However, a time consuming and unnecessary burden could be lifted from the courts if the initial decision were reached out of court. Denial of due process would not be an issue so long as judicial review were available whenever detention resulted from an agency decision. ${ }^{98}$ In addition, the agency would not be burdened with the necessity of maintaining extensive court liaison in order to present information and status recommendations.

The shifting of defendants from one status to another after the initial decision is usually accomplished, if at all, through cumbersome judicial bail review procedures ${ }^{00}$ which are limited to a review of the situation of those in jail. Rather than expand these procedures and place additional strains on the court's time, a consolidated pretrial agency acting on its own authority could more efficiently and effectively handle all of these subsequent decisions. Avoiding the delay caused by required judicial validation of all subsequent pretrial status recommendations could not only save the agency's time, effort, and resources, but could minimize as well any adverse effects on the individual defendant caused by such delay. Due process would again not be an issue if judicial review werc available whenever a subsequent agency decision resulted in detention. ${ }^{100}$

97. See pp. 156-57 \& notes 10-12 supra.

98. In nondetention situations the defendant should retain his right to appeal conditions that, although resulting in his release, he believes are too onerous. The prosecutor should also retain an ability to challenge status decisions that are not believed to be restrictive enough.

99. See p. 160 supra.

100. See note 98 supra. 
Clearly both initial and subsequent decisionmaking authority should lie with a single actor. If the court remained the initial decisionmaker and the agency were given authority to alter the defendant's status, the judge's decision would be a meaningless exercise. On the other hand, if the agency's ability to quickly alter status were curtailed, its effectiveness in dealing with defendants would be reduced. Lodging the power to make both decisions in one decisionmaker, preferably the agency, would avoid these difficulties.

\section{B. The Location of the Pretrial Agency in the Criminal Justice System}

There are at least three possible locations for a unified pretrial agency within the criminal justice system, any one of which, depending on local characteristics, may be the optimum arrangement:

1) The agency could be placed under the authority of the present administrators of detention facilities;

2) The courts could assume control of the agency; or

3) The agency could become an independent part of the criminal justice system.

\section{Administration by the Present Custodians}

The most expedient answer to the location question would be for the pretrial agency to become a subunit of corrections or law enforcement. ${ }^{101}$ The agency would be faced with fewer administrative boundaries which it would have to break down or draw anew, thus avoiding some of the confusion and delay which would otherwise be associated with creating a new organization. In addition, an agency under law enforcement would have closer contact with police programs such as citation release. ${ }^{102}$

There are, however, serious disadvantages with this arrangement. Present detention administrators do not view themselves as part of the spectrum of pretrial status alternatives. ${ }^{103}$ Inclusion of all seg-

101. See McGee, supra note 69, at 5-6.

102. See notes 10-11 supra.

103. Available evidence indicates that the present custodians do not adequately differentiate between pretrial detainees and other prisoners. The literature dealing with jail administration seldom mentions pretrial detention. Most striking in this regard is Blumer, Jail Management: A Course for Jail Administrators, Book Nos. 1-6 (1970), and especially Book 5 which discusses legal problems. Criticism of a pretrial facility by a member of the corrections department may simply be a call for more "correctional" programs for detainees not yet adjudicated to be in need of correction. Richmond, supra note 69, at 134. See also Moeller, Corrections and the Community: New Dimensions, 32 FED. Prob. 25, 29 (1968).

Focusing on particular administrators reveals the same attitude toward detainees. 
ments of the pretrial status process under their authority might well lead to a subordination of the pretrial functions to law enforcement or correction, especially with respect to internal resources allocation $^{104}$ and personnel management. ${ }^{105}$ Bureaucratic inertia alone would probably impede resolution of the judicially imposed task of rethinking both the conditions and the philosophy under which pretrial defendants are detained if the ultimate decisions had to be made by the custodians of convicted criminals.

\section{Administration by the Courts}

Court administration of nonjudicial functions is not a new concept $^{106}$ and the chief or administrative judges of some jurisdictions

For example, because pretrial detainees had been treated so badly in comparison to other prisoners in the past, a warden of the New Haven Correctional Center expressed pride in the fact that now "detainee and sentenced inmate are treated equally." Friedman and Solomon, The New Haven Community Correctional Center 5, 6 (unpublished paper on file at the Yale Law School Library).

Professor Daniel J. Freed of Yale Law School has noted that when detention administrators discuss pretrial detention,

the words they use will often be "unsentenced" or "pre-sentenced" prisoners, as

if it is only a matter of time before guilt is confirmed and detention is legitimated.

Frced, How Do W'e Divert More Offenders From the Criminal Justice System?, in National Conference on Corrections, We Hold These Truths . . 140 (1971). He also notes that "you will have to search hard through the architectural literature to find real differences between pretrial cages and cells for convicts." Id. at 140-41. See also $\mathrm{W}$. NAGEL, supra note 72 , at 18 .

104. For example, when the operation of the Manhattan Bail Project was assumed by the Office of Probation of the City of New York, an office which supervises persons who have been convicted, it was said that a disproportionate share of the resources of the Office were allocated to those who work with the convicted persons to the detriment of the pretrial release program. Partridge, supra note 6, at 9-10.

105. A related problem is that the local sheriff often holds an elective office. Political choice may thus determine jail conditions and employment at the jail may depend on political appointment. Alexander, Let's Look at Our Jails, 16 FED. PROB. 14, 15 (1952); Richmond, supra note 69, at 135-36; Note, Nebraska Jails, supra note 72, at 78. In addition, "piecework" compensation based on the number of detainees is occasionally the method for computing part of the sheriff's salary. Id. at 79. See also Wright, The Jail and Misdemeanant Institutions, in Contemporiry Corrections 310 (P. Tappan ed. 1951); H. Barnes \& N. TeEters, New Horizons in Criamology 390 (3d ed. 1959). This obviously decreases the sheriff's incentive to experiment with pretrial release.

106. The idea that a court should administer-programs in the criminal justice system that operate outside the courtroom is not novel. The Philadelphia Pre-Trial Services Division, directed by a deputy court administrator, is an example. See p. 161 supra. In many jurisdictions the probation department is a division of the courts, with judicial officers involved in preparing presentence reports as well as supervising offenders. See TASK FORCE REPORT: CORRECTIONS, supra note 2, at 35; Clark, Crime and Corrections, 3 CREIGHTON L. REv. 205, 212 (1970). In some areas the juvenile courts, as part of their broad responsibility under the philosophy of parens patriae, administer the local juvenile detention facility. See, e.g., President's Comarission on Law ENForcement AND ADMINistration OF JUSTICE, TASK FORCE REPORT: JUVENile DelinQUeNCY and Youth Crime 2 (1967); National Council on Crime and Delinguency, Detention Practice 185, 186, 190, 192, 195, 209, 213 (1960). It is interesting to note that at one time the courts in Connecticut did run the jails. ConNecticur GeneriL Assembly, Commission on Jails, Report of the Legislative Comisission on Jails, 1938, at 6 . 
have many nonadjudicatory responsibilities. ${ }^{107}$ Court administration of the unified pretrial agency could have several advantages. The present lack of appreciation of the pretrial defendant's special status might be substantially alleviated. In addition, the pretrial agency, as a subunit of the judiciary, could have expedited access to court records and other official information, and the question of decisionmaking authority could be more easily resolved. Members of the pretrial agency could be designated as judicial officers and given the authority to make certain status decisions. On the other hand, if the judge retained this authority, the agency could at least have greater access to the decisionmaker. ${ }^{108}$

There are, however, several problems associated with court administration of the pretrial status process. Just as in the case of administration by the custodians, the agency's budget and priorities would be subsumed within those of a larger element and possibly not given separate consideration. Resources might be more heavily requested for and allocated to the court's primary function, adjudication, to the detriment of pretrial status alternatives. ${ }^{109}$ Perhaps most important, the judicial image of neutrality might be impaired. Attorneys might hesitate to file suits concerning the unreasonable administrative procedures of the court's own agency. And appeals by detainees might be affected if they came to view the judge as their jailor as well as the overseer of jail conditions and the adjudicator of their guilt or innocence.

\section{Independent Administration}

A third alternative would be to make the pretrial agency a new and independent component of the criminal justice system. The executive of a given jurisdiction could create a Department of Pretrial Services and appoint its administrator, much as is presently

107. Historically, most courts have been administered by the presiding judge and the clerk. Oglesby \& Gallas, Court Administration-A New Profession: $A$ Role for Universities, 10 AM. Bus. L.J. 1, 7 (1972). Although suggestions have been made for cxpanding the tasks of the administrative judge, see Berg, Assumption of $A d-$ ministrative Responsibility by the Judiciary: Rx for Reform, 6 SUFFolk U.L. REV. 796, 801 (1972), these duties are now increasingly being given to professional court administrators. Oglesby \&: Gallas, supra; Commentary, Court Administration: The Newest Profession, 10 DuQuesne L. Rev. 220 (1971).

108. For example, in Philadelphia the court-run Pre-Trial Services Division is able to present petitions to the court at any time as a matter of course. Lester Interview, supra note 53.

109. The courts are having enough trouble obtaining sufficient funds to perform their adjudicative role. See, e.g., Hazard, McNamara, \& Sentilles, Court Finance and Unitary Budgeting, 81 YALr L.J. 1286, 1287 (1972). But cf. note 110 infra. 
done with the Department of Corrections and the Department of Police Services.

There are two primary advantages of such an arrangement. First, the total separation of the pretrial system from the convict and his custodians could bring to the attention of legislators and voters the crucial distinction between pretrial defendants and convicted persons: Pretrial defendants are presumed innocent and must be treated accordingly. Second, separation would help ensure that the pretrial agency's budgetary need would not be neglected for the benefit of another element of the criminal justice system. Short-range diversion of funds from the agency could thus be avoided.

A major potential disadvantage that such an independent agency might encounter, however, is lack of its own political power. ${ }^{110}$ It would not be able to rely on the lobbying ability of any recognized element of the criminal justice system and would be administering many new and controversial functions. Adequate funding from limited local sources might thus be quite difficult to obtain.

\section{Conclusion}

Regardless of the organizational position a pretrial agency would occupy in the criminal justice system, centralized administration of the entire spectrum of pretrial status alternatives could permit comprehensive reform in all three of the primary decisionmaking areas: Both the initial and subsequent status decisionmakers could be presented with more complete information on the defendant and could have a wider range of status alternatives from which to choose, while funding could reflect a more accurate assessment of the needs of all the various elements of the pretrial process. Given the current existence of unnecessary detention, the resulting improvement in pretrial status decisionmaking could lead to the release of more pretrial defendants and the imposition of more appropriate restrictions while costs and the failure to appear rate remained within acceptable ranges. Empirical verification of these potential benefits awaits the creation of comprehensive pretrial agencies.

110. The present director of the Philadelphia Pre-Trial Services Division, who was previously the Court-Coordinator of the Washington, D.C., Bail Agency, noted the effect that independent administration has during funding battles. The D.C. Bail Agency, he said, was primarily "independent," but lacking in political power. No powerful element in the system would support it in funding battles, and Agency programs accordingly suffered. His new employer, the Pre-Trial Services Division, on the other hand, is clearly a part of the court system. Since the courts were a more established portion of the criminal justice system, the judges were able to "go to bat" for the Division in order to obtain increased funding. Gedney Interview, supra note 61 . 